\title{
AN ERGONOMIC ANALYSIS OF DRUDGERY PRONE ACTIVITIES IN SUGARCANE CULTIVATION
}

\author{
PARIMALAM $\mathrm{P}^{1}$, MEENAKSHI $\mathbf{J}^{\mathbf{2}}$ \& PADMINI D $\mathrm{S}^{\mathbf{3}}$ \\ ${ }^{1}$ Professor and Head, Department of Family Resource Management, \\ Home Science College \& Research Institute, Madurai, Tamil Nadu, India. \\ ${ }^{2}$ Research Associate, AICRP on Home Science, Home Science College \& \\ Research Institute, Madurai, TamilNadu, India. \\ ${ }^{3}$ Senior Research Fellow, Department of Family Resource Management, \\ Home Science College \& Research Institute, Madurai, TamilNadu, India
}

\begin{abstract}
Sugarcane is the third largest crop, cultivated next to rice and wheat in our country. In Tamilnadu, about 3.52 lakhs hectares of land are under sugarcane cultivation and this is increasing annually due to the increased consumption of sugar, and also the growing demand from mills for sugarcane as a raw material. Thirty farm women involved in different stages of sugarcane cultivation from five villages of Madurai district have been interviewed and data was collected for characterization of drudgery, by interview method. Six Parameters namely, physical load carrying, Posture, Repetitive strain, Time, Muscular-Skeletal Disorders (MSD) and Physiological load were considered, for the drudgery assessment. Activities like sett planting, weeding and harvesting were considered for data collection, as these activities were carried out by majority of the farm women. The data revealed that, the drudgery index was found to be more for carrying of harvested sugarcane from the field to the processing unit (43.49), which was followed by sett planting (35.27), cutting of matured sugarcane (32.61), weeding (31.59) and gathering and bundling of harvested sugarcane (30.94). Based on the drudgery index, the activities were categorized for drudgery level and the activities under the study were found to be in the category of 'moderately heavy'. Based on the findings, it is suggested that, low cost intervention which is practically feasible and acceptable by the workers is, to be introduced to reduce the drudgery load.

KEYWORDS: Drudgery, Sugarcane, Assessment \& Drudgery Index
\end{abstract}

Received: Jun 30 2017, Accepted: Jul 18 2017, Published: Jul 26 2017, Paper Id: IJASRAUG201757

\section{INTRODUCTION AND BACKGROUND}

Agriculture is the backbone of the Indian economy. Women play a vital role in building this economy. Over the years, there is a gradual realization of the key role of women in agricultural development and their vital contribution in the field of agriculture, food security, horticulture, processing, nutrition, sericulture, fisheries, and other allied sectors. More than half of the world's food is grown by women. Women's work is both wide-ranging and multifaceted throughout the year, and they perform multiple tasks in the sphere of agriculture. Women's indigenous knowledge and skills are vitally necessary for food production and sustainable agriculture (Singh and Arora, 2010).

Sugarcane is the third largest crop cultivated next to rice and wheat in our country. The second largest 
agro-based industry next to cotton textiles is sugar industry. In Tamilnadu, about 3.52 lakhs hectares of land are under sugarcane cultivation and this is increasing annually due to the increased consumption of sugar and also the growing demand from mills for sugarcane as a raw material.Women play a significant and crucial role in various operations like planting, weeding, and harvesting. (Mohanta and Patra 2015).Similar trend of work pattern was also observed among farm women engaged in sugarcane cultivation.

Women perform a series of activities such as sett planting, weeding, propping, cutting and carrying of harvested sugarcane across the fields for stacking in the lorries / transport vehicles.As a result of these activities over a period of more than eight hours, they face several occupational health hazards. The identification of occupational health hazards and the development of systems to evaluate intervene, and decrease musculoskeletal risk factors and resulting disorders can be quite labor intensive and will require extensive occupational health knowledge. In this context, the present study was undertaken with the identify the drudgery prone activities performed by the women in sugarcane cultivation.

\section{METHODOLOGY}

Five villages of Madurai district of Tamilnadu were selected for the study as the major crop cultivated in these villages was found to be sugarcane. A total of thirty farm women involved in different stages of sugarcane cultivation from the selected five villages were interviewed regarding the drudgery prone activities. A standardized interview schedule was used to collect the data from farm women. The data consisted of demographic details of the farm women, the crop calendar and drudgery assessing parameters like Physical load carrying, Posture, Repetitive strain, Time, MSDs and Physiological load. The Criteria adopted for selection of farm activities was gender participation i.e., women exclusive, women dominant and women equal participation. The details of parameters for drudgery characterization and the variables studied with scores are depicted in the Table 1.

Table 1: Parameters for Characterization of Drudgery in Sugarcane Production System

\begin{tabular}{|l|l|l|l|}
\hline S. No. & \multicolumn{1}{|c|}{$\begin{array}{c}\text { Drudgery } \\
\text { Parameter }\end{array}$} & \multicolumn{1}{|c|}{ Variables } & \multicolumn{1}{c|}{$\begin{array}{c}\text { Qualitative Perception Rating } \\
\text { 5 Points }\end{array}$} \\
\hline 1 & $\begin{array}{l}\text { Physical load } \\
\text { carrying }\end{array}$ & $\begin{array}{l}\text { Weight of the load ( kg) } \\
\text { Distance of load displacement } \\
(\mathrm{km}) \text { Height lifted }\end{array}$ & $\begin{array}{l}\text { Physical load } \\
\text { Very heavy - very light (5 - point score) }\end{array}$ \\
\hline 2 & Posture & $\begin{array}{l}\text { Nature of posture } \\
\text { Body part involved }\end{array}$ & Postural discomfort rating \\
\hline 3 & $\begin{array}{l}\text { Repetitive } \\
\text { Strain }\end{array}$ & Frequency of repetitions & Repetitive strain rating score \\
\hline 5 & Time & $\begin{array}{l}\text { Hours / day } \\
\text { No. of days } \\
\text { No of labour employed }\end{array}$ & $\begin{array}{l}\text { Time load rating, Very high duration - Very } \\
\text { less duration }(5-\text { point score) }\end{array}$ \\
\hline 6 & $\begin{array}{l}\text { Physiological } \\
\text { load }\end{array}$ & Heart rate & Pain rating \\
\hline
\end{tabular}

\section{RESULTS AND DISCUSSIONS}

\section{Farm Women Participation}

Both men and women participated in the sugarcane cultivation in various farm activities in the selected villages. Observation of various farm activities involved in sugarcane production was carried out and the crop calendar of the 
selected crop was also recorded to understand the locally adopted farm practices in the selected villages. The criterion for selection of farm activities was based on gender participation. The following table gives information on list of farm activities in sugarcane production system and participation of farm men and women in each activity.

Table 2: Farm Activities and Gender Participation in Sugarcane Production System

\begin{tabular}{|l|l|l|}
\hline \multicolumn{1}{|c|}{ Duration } & \multicolumn{1}{c|}{ Activities } & \multicolumn{1}{c|}{$\begin{array}{c}\text { Gender } \\
\text { Participation }\end{array}$} \\
\hline \multirow{2}{*}{$1^{\text {st }}$ month } & Land preparation & ME \\
\cline { 2 - 3 } & Sett planting & WE \\
\cline { 2 - 3 } $2^{\text {nd }}$ month & Manuring & ME \\
\hline $3^{\text {rd }}$ month & Weeding & WE \\
\hline $4^{\text {th }}$ month & Weeding & WE \\
\hline $5^{\text {th }}$ month & Weeding & WE \\
\hline $6^{\text {th }}$ month & Plant protection - Detrashing\& Propping & WE \\
\hline $7^{\text {th }}$ month & Fertigation & ME \\
\hline $\begin{array}{l}8^{\text {th }} \text { month to } 11 \\
\text { month }\end{array}$ & Fertigation & ME \\
\cline { 2 - 4 } & Harvesting & EP \\
\hline
\end{tabular}

WE - Women Exclusive; ME - Men Exclusive; EP - Equal Participation

The participation of women exclusive farm activities in sugarcane production was Sett planting, weeding and plant protection i.e., Detrashing and Propping. An equal participation of farm men and women was followed in harvesting (Crop cutting, gathering, bundling, and manual carrying) and post harvesting of sugarcane cultivation.

Based on the gender participation in sugarcane production system, thirty farm women performing field activities in sugarcane production system such as weeding and harvesting were interviewed for their perception of characterization of drudgery in the farm activities involved. The drudgery parameters such as physical load, posture load, repetitive strain load, time load, MSDs and physiological load were assessed. The total drudgery of all the parameters was calculated as follows:

$\operatorname{dr}($ Total $)=\operatorname{dr}(P L)+\operatorname{dr}(P)+\operatorname{dr}($ RS $)+\operatorname{dr}(T)+\operatorname{dr}($ MSDs $)+\operatorname{dr}(\operatorname{PysL})$

where dr(Total) - Total drudgery ; PL - Physical load (25 points); P - Posture load (25 points); RS - Repetitive strain load (25 points); T - Time load (25 points); MSDs - Musculoskeletal Disorders (25 points); PysL - Physiological load (25 points)

\section{Drudgery Index \% (DI) $=[100 \times$ dr $($ Total $)] / 150$}

Drudgery level categorization

$$
\begin{aligned}
& <15=\text { Very low } \\
& 15-30=\text { Low } \\
& 30-45=\text { Moderate to Heavy } \\
& 45-60=\text { Heavy }
\end{aligned}
$$


$60-80=$ Very heavy

$>80=$ Unacceptable

Table 3 presents the details of the different load factors for the activities carried out for sugarcane cultivation

Table 3: Drudgery Load of Activities in Sugarcane Cultivation

\begin{tabular}{|l|c|c|c|c|c|c|c|}
\hline Farm Activity & $\begin{array}{c}\text { Physical } \\
\text { Load }\end{array}$ & $\begin{array}{c}\text { Posture } \\
\text { Load }\end{array}$ & $\begin{array}{c}\text { Repetitive strain } \\
\text { Load }\end{array}$ & $\begin{array}{c}\text { Physiological } \\
\text { Load }\end{array}$ & $\begin{array}{c}\text { Time } \\
\text { Load }\end{array}$ & $\begin{array}{c}\text { MSD } \\
\text { Total } \\
\text { Drudgery } \\
\text { Load }\end{array}$ \\
\hline Sett Planting & 0.47 & 7.69 & 8.07 & 2.53 & 18.13 & 16.02 & 52.91 \\
\hline Weeding & 1.70 & 9.24 & 7.67 & 6.07 & 10.27 & 12.44 & 47.39 \\
\hline $\begin{array}{l}\text { Harvesting - Crop } \\
\text { Cutting }\end{array}$ & 3.24 & 7.13 & 7.33 & 9.24 & 12.9 & 9.08 & 48.92 \\
\hline $\begin{array}{l}\text { Gathering \& } \\
\text { Bundling }\end{array}$ & 2.40 & 6.44 & 9.97 & 8.20 & 7.64 & 11.77 & 46.42 \\
\hline $\begin{array}{l}\text { Carrying of } \\
\text { harvested sugarcane }\end{array}$ & 16.17 & 10.16 & 6.17 & 9.54 & 5.00 & 18.20 & 65.24 \\
\hline
\end{tabular}

Analysis of the different load factors reveled that manual carrying was the most drudgery prone activity followed by sett planting. The reasons for this may be due to the increased musculoskeletal discomfort of the workers with longer duration of time period. Figure 1 presents the drudgery index of these activities performed by women. A similar trend was even observed in the drudgery index.

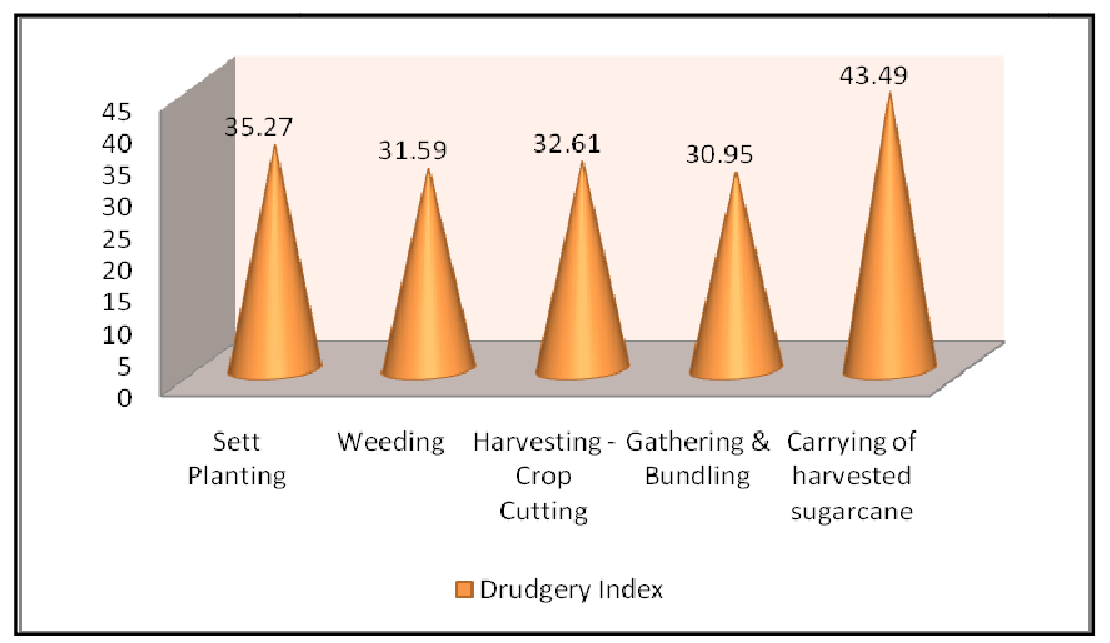

Figure 1: Drudgery Index of Farm Women in Performing Sugarcane Farm Activities

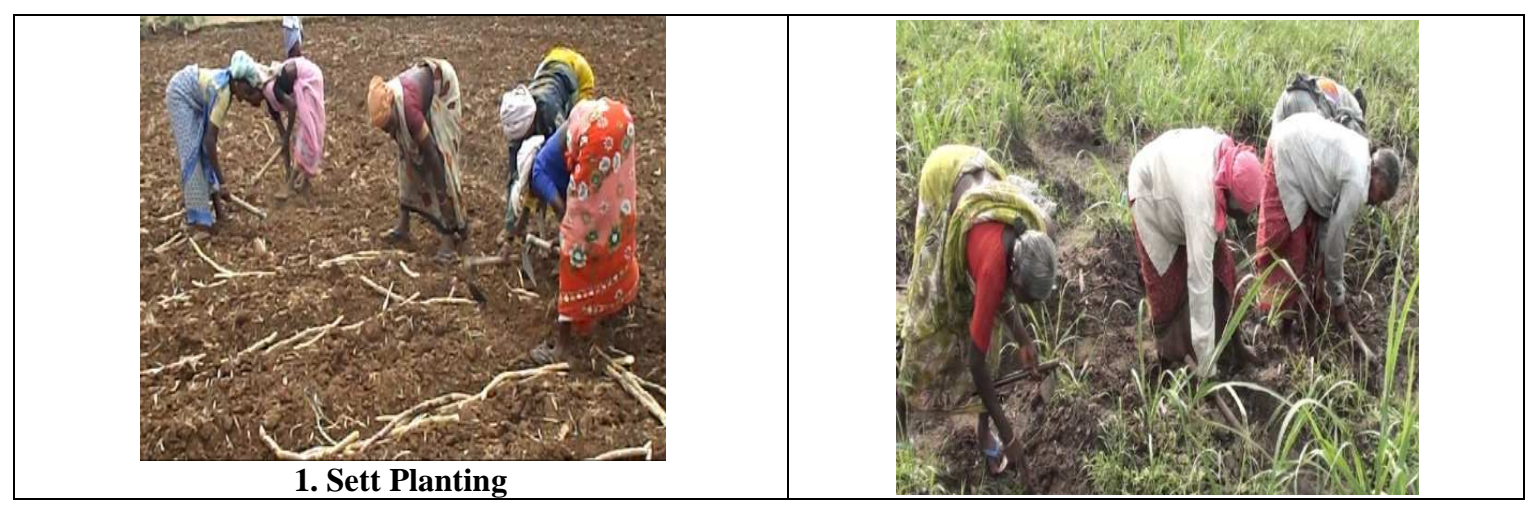




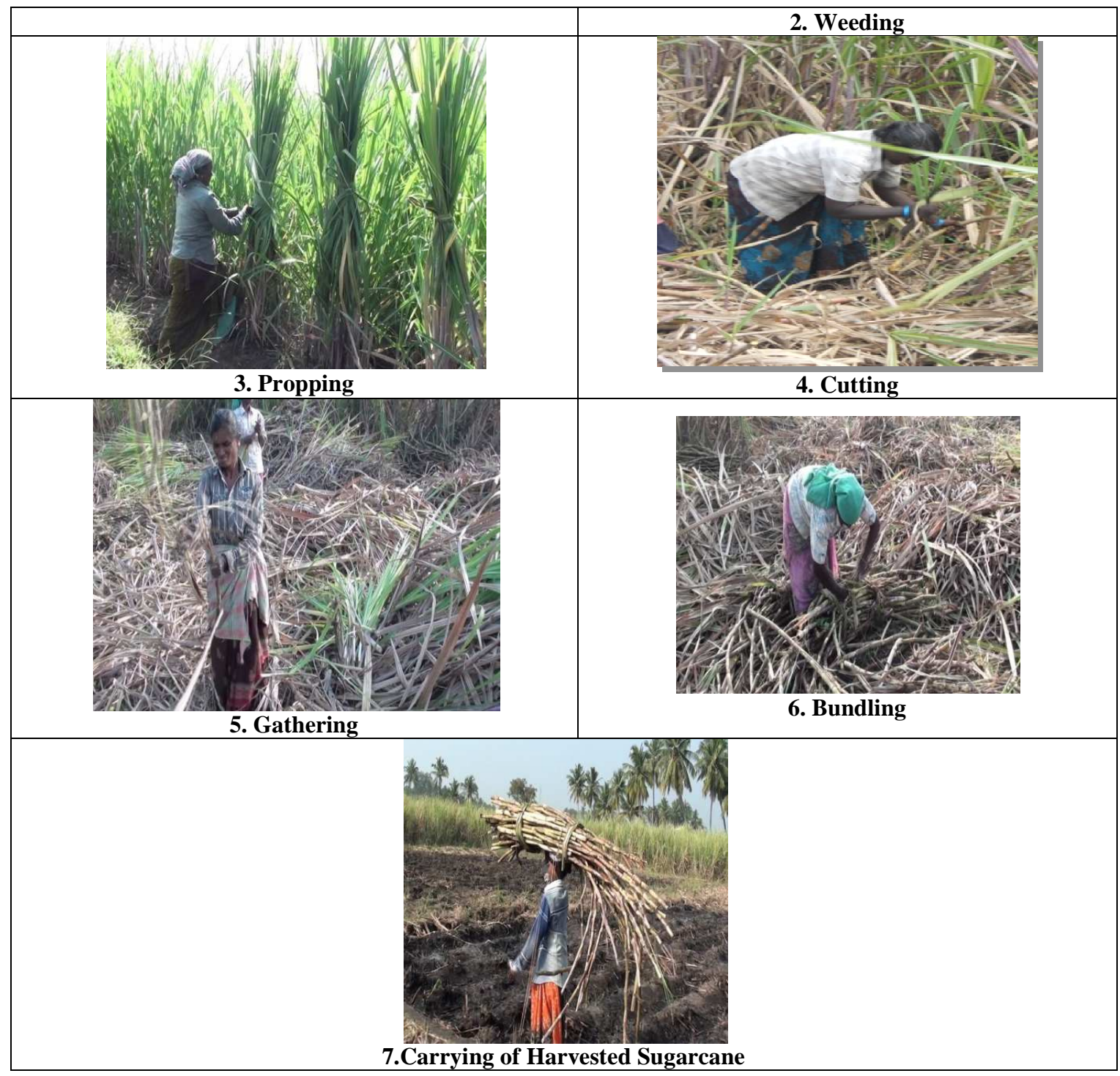

Figure 2: Sequence of Major Activities Involved by Farm Women in Sugarcane Production System

Assessment of the drudgery prone activity in sugarcane production system will help in quantify the drudgery of farm women in this particular production system. Minimizing the drudgery through suitable intervention in terms of improved agricultural tools and implements, use of personal protective clothing and awareness generation among the farming community on these technologies will benefit the farming community in improve the health profile of farm women and thereby reduce the injuries that are involved in agriculture. Promoting health of farm women will enhance their productivity and thereby increase their socio-economic status. Increased production helps to earn a better income of farm women.

\section{CONCLUSIONS}

Sugarcane cultivation has increased level of women participation in selected activities. Carrying the harvested sugarcane through the fields exerts the farm women to a great extent and needs some kind of mechanization where the harvested sugarcane can be stacked directly into the vehicles. Based on the findings of the present study, it is suggested 
that low cost intervention which is practically feasible and acceptable by the workers has to be introduced to reduce the drudgery load.

\section{ACKNOWLEDGEMENT}

The authors are thankful to Indian Council of Agricultural Research (ICAR) - Central Institute for women in Agriculture (CIWA) for funding the research work. Also the authors acknowledge the farm women who co-operated during the research period.

\section{REFERENCES}

1. Kishtwaria. J and A. Rana. 2012. Ergonomic interventions in weeding operations for drudgery reduction of hill farm women of India. Work 41: 4349-4355.

2. Mrunalini. A., D. Esther, and J. Deepika. 2015. Characterization of drudgery in cotton production systems. International Journal of Agricultural Science and Research 5(2): 147-152.

3. Pheasant S. Ergonomics, Work and Health. Macmillan Press; 1995. pp. 261-267

4. Mohanta. B and D. Patra. 2015. Ergonomic study on sugarcane stripper for drudgery reduction of female farm workers. Asia Pacific Journal of Research I (28):216-220.

5. Singh. S and R. Arora. 2010. "Ergonomic Intervention for Preventing Musculoskeletal Disorders among Farm Women”. J AgriSci, 1(2): 61-71.

6. Shanthy.T.R.2010. "Gender Perspectives for Sustaining Sugarcane based Farming System”. Indian Res. J. Ext. Edu.10 (1):112-116. 